\title{
The Certainty of Return on Investment in the Toll Road Concession Agreement Due to the Replacement of Land Procurement for Toll Road by Using the Bailouts Fund of Toll Road Business Entities
}

\author{
Saktia Lesan Dianasari ${ }^{1}$; Adi Sulistyono ${ }^{2}$; Hari Purwadi ${ }^{2}$ \\ ${ }^{1}$ Student of Magister Business Law, Universitas Sebelas Maret, Indonesia \\ ${ }^{2}$ Lecturer at the Faculty of Law, Universitas Sebelas Maret, Indonesia \\ http://dx.doi.org/10.18415/ijmmu.v8i8.2903
}

\begin{abstract}
This study has purpose to determine the certainty of return on investment in the toll road concession agreements due to the replacement of land procurement for toll road by using the bailout funds of toll road business entities. This study was conducted by using a normative legal research with a comparative approach. The data used in this study were secondary data. The data collection technique in this study was done through literature study. The data were analyzed by using deductive legal material analysis techniques. From the results of the research and studies, it was found that the use of bailouts fund from the toll road business entities was ineffective and there were still some obstacles in its implementation.
\end{abstract}

Keywords: Bailouts; Toll Road Business Entity; Land Procurement

\section{Introduction}

Indonesia is one of the countries where the infrastructure sector is still lagging behind other countries and requires development, one of which is the construction of the Trans Java toll road and outside Java toll road. In this infrastructure development, it is inseparable from the land acquisition or procurement. In this case, land has several economic, political, and legal and social aspects. ${ }^{1}$ Land is one of the most important natural resources and is an important factor in human life which is given by God Almighty as a source of livelihood in earning a living, a place to stand, and to live and carry out daily activities. For the Indonesian people, land is a national wealth and the human need for land continues to increase with the times. The factors that influence the increasing demand for land are the increase in population and technological advances which in turn increase the standard of human life. To make it easier and to support human activities, it is necessary to construct supporting facilities and infrastructure, such as road construction, hospitals, school buildings, places of worship, airports, train stations and others. Such development, certainly, requires a lot of land as a place or location to carry out the

\footnotetext{
${ }^{1}$ Winangun, Y. W. Land of Life Value. 21.
} 
development activities. The land acquisition or procurement process is very prone to handling since it contains the livelihood of many people, the land acquisition process will not be separated from the problem of compensation, thus, it is very important to conduct research, identification and inventory of land data as a basis for making an estimate of the compensation in order to reach an agreement regarding the form and amount of the compensation.

In the implementation of land procurement, it is not only land owned by individuals but also Village Treasury Land (TKD) which is also subject to the regulations regarding the release of TKD. Law Number 5 of 1960 concerning the Basic Agrarian Principles or better known as the Basic Agrarian Law (UUPA) which is a legal provision to regulate the agrarian sector or land regarding the main issues of agrarian affairs. The purpose of the issuance of the UUPA is essentially to realize the statement outlined in the Article 33 paragraph (3) of the 1945 Constitution of the Republic of Indonesia which states that the earth, water and natural resources contained therein, whose authority is assigned to the Republic of Indonesia, must be used as much as possible for the prosperity of the people. During its development, the land problem is increasingly complex, thus, its dimensions continue to increase following the dynamics of the pace of national development, including juridical, economic, political, social, religious and magical dimensions, even for the State, land has a strategic dimension. ${ }^{2}$ Arrangement of land for the purposes of development for the public interest through revocation of rights or relinquishment of rights over land belonging to the community must be regulated in a law that reflects the respect for human rights.

The latest policy regarding land acquisition for the public interest in Indonesia is regulated in Law of the Republic of Indonesia Number 2 of 2012 concerning Land Acquisition for the Development for Public Interest. With the existence of this Law, it is expected that the land acquisition or procurement process for the national development involving the development of public interests requiring land as a location can be carried out as well as possible. Furthermore, as a follow-up to Law Number 2 of 2012, Presidential Regulation Number 71 of 2012 concerning the Administration of Land for the Development for Public Interest has been issued. Thus, it becomes a necessity for the apparatus of State Institutions (Ministries, Non-Ministries, Provincial Governments, Local Governments), State-Owned Legal Entities, State-Owned Enterprises that receive special assignments from the Government, academics and all elements of society related to land acquisition or procurement to understand and guide the regulations on the land procurement so that starting from the stages of planning, preparation, implementation, and submission of the results of the Land Acquisition for the development in the Public Interest, it can be carried out effectively, efficiently, and in compliance with the principles. ${ }^{3}$

One of the problems that often occur in the process of land procurement for the public interest is the determination of the amount of compensation. This problem occurs since the Land Procurement Committee (PPT) offers low land prices, while the communities as the rights holders request for a high land price. The determination of land prices has actually been carried out by the land price interpretation team in accordance with the provisions of the Indonesian Appraisal Standard, but the community tends to insist on the requested price and exceeds the land price. Furthermore, it is regarding the payment period, although the payment period has been regulated in Law Number 2 of 2012 concerning the Land Acquisition for the Development for Public Interest, the payment period also depends on the source of funding. In this case, it is the source of funding that can be derived from the bailout fund from the Toll Road Business Entity or it can come directly from the State Asset Management Agency or so-called as LMAN.

A total of 47 toll roads are one of the infrastructures that are the object of acceleration by the government and are part of the National Strategic Project (PSN). In early 2015, the Committee for the Acceleration of Priority Infrastructure (KPPIP) found the fact that land problems were in the first rank of

\footnotetext{
${ }^{2}$ Darwin Ginting, “ Kapita Selekta Agrarian Law ”, Jakarta: Fokusindo Mandiri, 2013, p. 122.

${ }^{3}$ BPN RI Land Office of Semarang, Land Acquisition for the Development of Public Interest, ( 2013), ii.
} 
problems, it was $44 \%$ of the problems reported in PSN. ${ }^{4}$ Payment through LMAN and Toll Road Business Entity bailout funds is a government innovation to accelerate the land acquisition process, in accordance with Presidential Regulation Number 102 of 2016 concerning Land Acquisition Funding for the Development for Public Interest in the Context of Implementing National Strategic Projects, however, in fact, there are many obstacles appear in the field during the application of the Presidential Regulation. By utilizing the momentum of the crisis through infrastructure development, it is expected that the readiness of this infrastructure will become the investment competitiveness of Indonesia when the crisis subsides. Consequently, this increased competitiveness will potentially increase the inflow of investment, which in turn will be able to accelerate the economic growth. By paying attention to the importance of infrastructure development in increasing the investment competitiveness, the policy to encourage infrastructure development, in this case in the transportation sector, is the right decision since it can invite public and private cooperation. The need for private participation is based on the fact that one of the most crucial problems faced by the developing countries, including Indonesia, is the limitations that these countries have in their efforts to prepare the adequate infrastructure. The kind of infrastructure, such as transportation, is a very fundamental requirement in order to drive the economy.

These limitations are multi-dimensional, since they are not only related to the problem of limited sources of funding/ financing, but also the limited capacity of human resources, technology and even management. Considering that the fulfillment of these infrastructure needs is something that must be prioritized for handling, it is necessary to look for efforts to overcome this limited situation. One of the many efforts that have been made is to invite the participation of "private sectors" to invest in the transportation sector. The pattern that is often used in infrastructure development in the transportation sector is to use the BOT ("Build, Operate and Transfer") pattern followed by the making of the PPJT (Toll Road Concession Agreement) as a business contract with a public dimension between the Government and (private) investors in the infrastructure projects. The choice of this pattern is based on the various advantages it can offer, especially for the government, while for investors, instead of the potential benefits that can be obtained, it also carries the risk of loss. To attract private investment in the infrastructure development in the transportation sector, a mechanism that is able to minimize their losses is also needed, which is through the forms of investment protection that can be offered by the government. Minimizing losses through investment protection schemes will be an incentive that can create a better investment climate.

From the above description, the writer is interested in discussing the process of providing compensation by using bailout funds and certainty of return on investment in the toll road concession agreements due to the replacement of land procurement for toll road by using toll road business entity bailout funds.

\section{Methodology}

Doctrinal Law Research is a research on laws that are conceptualized and developed on the basis of the doctrine adhered to by the conceptualist or by the developer. In Indonesia, doctrinal methods are commonly referred to as normative research methods. ${ }^{5}$ According to Peter Mahmud Marzuki, normative legal research is a process to find a rule of law, legal principles, and legal doctrines to answer the legal problems at hand. Normative legal research is carried out to produce new arguments, theories or concepts as prescriptions in solving the problems at hand. ${ }^{6}$ The technique of collecting the legal materials used in this legal study is library research, which is a research conducted by using the secondary data. ${ }^{7}$ The writer

\footnotetext{
${ }^{4}$ Alfred Nobel, Nabila Putri Larasati, "Land Financing Innovations for Toll Road Projects Included in National Strategic Projects Using the Bailout Fund Mechanism ", Journal of HPJI Vol. 3, No. 2, 2017, 140

${ }^{5}$ Sulistyowati Irianto and Shidarta, Legal Research Methods: Constellation and Reflection, Yayasan Pustaka Obor, Jakarta, 2013 , p 121.

${ }^{6}$ Peter Mahmud Marzuki, Legal Research, Kencana, Jakarta, 2008, p. 141-169.

${ }^{7}$ Ronny Hanitijo Soemitro, Legal and Jurimetric Research Methodology, Ghalia Indonesia, Jakarta, 1990, p 11.
} 
collects the legal material in the form of secondary data and studies to obtain answers to the problems that want to be studied in a legal research.

This study applied deductive legal material analysis techniques. Deductive logic is a way of thinking that starts from the notion that something that applies to an entire event or group or type also applies to each element in that group or type of event. ${ }^{8}$

\section{Results and Discussion}

The government has various inherent powers, but on the other hand, legal protection for citizens is an obligation that must be carried out by the government as stipulated in the 1945 Constitution, in this case not only residents affected by the project but also the Toll Road Business Entities where in the toll road land acquisition or procurement, this business entity acts as a manager and acts as the party that provides bailout funds for the land procurement and on the other hand the Government with all its instruments as the main pillar of state administration is increasingly faced with the global complexities. Its role must be able and careful to proactively accommodate all forms of changing economic conditions. This condition is very possible because the apparatus is in the position of formulating and determining policy power, as implementing regulations, through higher hierarchies to lower hierarchies. ${ }^{9}$

In the practice, the use of bailout funds is ineffective and the process seems to take longer since various challenges and problems arise as a consequence of regulatory changes and changes in the domestic and global economic conditions, as well as land procurement for the public use for toll roads. In addition, the process of providing compensation, which requires time and a long mechanism, is an unavoidable problem. This is what causes the ineffective provision of compensation by using the Toll Road Business Entity bailout; therefore, the writer is interested in further examining the obstacles that occur in the field. The obstacles that occur are as follows:

1. There is no synchronization between Law Number 2 of 2012 and the implementing regulations, the Presidential Regulation Number 71 of 2012 article 76 paragraph 4 "The provision of compensation as referred to in paragraph (2) shall be carried out no later than (7) seven working days from the stipulation of the form of Compensation for Land Procurement Implementers and Presidential Regulation No. 102/2016 on Land Acquisition Funding for the National Strategic Projects;

2. Payment procedures/ mechanisms that go through several processes and exceed the payment time set out in the Presidential Regulation Number 71 of 2012 as mentioned in point 1 (one) above which causes landowners to be impatient and ask for price increases, which results in delays of land procurement, then results in the inconsistencies in the computation of the business plan that was agreed upon at the outset between the Toll Road Business Entity and the Toll Road Regulatory Agency, since, without exception, the Business Entity must pay rent to the residents affected by the project above or to the land of the Village Treasury affected by the project.

3. It is not followed by an addendum to the Toll Road Concession Agreement as a result of changes in the regulations related to Land Acquisition for the Development for Public Interest, especially regarding the Toll Road Business Entity Bailout Funding/ Funding for the Land Procurement.

4. Toll Road Business Entities in applying for bailout fund replacements are also not immediately replaced by the Government, thus, there is no certainty that the bailout funds will all be replaced, even

\footnotetext{
${ }^{8}$ Mukti Fajar Nur Dewata and Yulianto Achmad, Dualism of Legal Research: Normative and Empirical, Learning Library, Yogyakarta, 2010, p. 109.

${ }^{9}$ Lijan Poltak Sinambela,et. al., Public Service Reform "Theory, Policy, and Implementation", PT. Bumi Aksara, Jakarta, 2017 , p.34.
} 
though the Business Entities in giving the bailout fund for land payments are the proceeds from a syndicated bank loan that must be paid every month along with the loan interest, if there is no certainty about the time the bailout funds will be returned, it will also affect the cash flow of the business, as for applying for the bailout replacement funds, the Business Entity also goes through several processes, which is a review of the BUJT bailout fund replacement by the State Asset Management Agency (LMAN) based on a review from the Provincial Financial and Development Supervisory Agency (BPKP), and the review is not immediately used by the State Asset Management Institute (LMAN), and LMAN is still conducting another review, even though the authority to review by LMAN is not regulated.

In relation to the problem of using the Toll Road Business Entity Bailout Funds for the payment of compensation for the community land and the village treasury affected by the land procurement projects for toll road construction, thus, the settlement efforts made to overcome the obstacles that arise are as follows:

1. An adjustment or revision is required in the regulation of Presidential Regulation Number 102 of 2016 concerning Funding of Land Acquisition for National Strategic Projects, especially in terms of the funding process. It is expected that the process that must be passed in the disbursement of bailout funds is in accordance with the applicable regulations. If the process does not comply with the applicable regulations, it can obstruct and create chaos in the implementation of land acquisition which will also result in disruption of investment by the Toll Road Business Entity itself.

2. Regarding the land of the residents who are affected by the project, there is a need for certainty of payment time, thus, it is necessary to revise the Presidential Regulation Number 71 of 2012 regarding the period of payment of compensation. Then, for the Village treasury land, the process of finding replacement land in a local village or village in one sub-district or village in another adjacent subdistrict may become more difficult, therefore, at first, a replacement can be given in the form of money for the replacement land, thus, (article 33 paragraph (2) letter b Permendagri No.1/ 2016 concerning Village Asset Management has not been implemented optimally, since, in this far, the Toll Road Business Entities do not want to process the bailout funds if the village has not received the replacement land, in this case, the replacement land owners also need certainty about the time of payment. Therefore, the revision of this article by adding an article that regulates the procedures and mechanism for compensation given in the form of money is needed. Then, related to the exchange procedure/ mechanism which take a long time until the Governor's Permit causes the replacement land owner to transfer to another party, it is necessary to have regulations which regulates the giving of money as down payment to the replacement land owner, thus, revisions to the article 33 Permendagri No.1 of 2016 concerning Village Asset Management by adding the additional articles are also needed.

3. There is a need for a Standard Operating Procedure related to a review of the BUJT bailout reimbursement by the State Asset Management Agency (LMAN) and a review by the Financial and Development Supervisory Agency (BPKP), which states that it is eligible and uneligible for complete and incomplete files, which sometimes carried out with a lack of understanding of the auditor, so that the file is declared uneligible/ incomplete (even though the file is validated by the Head of Land Acquisition Committee). This must not occur due to the following reasons:

a. If the files have been validated by the Chief Executive of Land Acquisition who has the authority to recommend eligible or uneligible files, the review authority by the State Asset Management Agency (LMAN) and the Review of the Financial and Development Supervisory Agency (BPKP) will overlap, which causes the process of providing compensation of the village treasury land takes longer. 
b. An Exit Meeting is required in the review, involving policy makers from the State Asset Management Agency (LMAN), the Financial and Development Supervisory Agency (BPKP), Land Institutions, Commitment Making Officials (PPK) and Toll Road Business Entities.

4. An addendum to the Toll Road Concession Agreement is required in relation to changes in the regulations regarding the use of the Toll Road Business Entity Bailout Fund to ensure the certainty of return on investment that has been issued by the Toll Road Business Entity due to inconsistencies with the calculation of the business plan that has been agreed between the Toll Road Business Entity and the Toll Road Regulatory Agency as stated in the Toll Road Concession Agreement.

\section{Conclusion}

The process of granting the land compensation by using the bailout funds from the toll road business entities must be regulated in significant detail since it will not only affect the length of the payment process, but will also affect the cash flow of the business entity, therefore it would be better if the regulations were related to the length of the payment process and the Standard Operating Procedures related to the replacement of bailout funds that have been issued by the toll road business entity are described in detail. After the regulation is revised, it will be followed up with an addendum to the agreement that regulates and protects the investment of the Toll Road Business Entity.

\section{Suggestion}

The government should more actively socialize the rules to the community and the related stakeholders regarding the land acquisition funding for toll roads and have a common understanding of these regulations. The government also needs to listen more to the problems and obstacles faced in the field related to the payment process using bailout funds and the process of returning the bailout funds by LMAN (State Asset Management Institute.

\section{References}

BPN RI Semarang Land Office, Central Java Province. (2013). Land Acquisition for the Development for Public Interest. BPN RI

Darwin Ginting. (2013). Capita Selecta of Agrarian Law. Jakarta: Fokusindo Mandiri.

Lawrence M. Friedman. (2009). Legal System: Social Science Perspective. Bandung: Nusa Media.

Lijan Poltak Sinambela, et al., (2017). Public Service Reform "Theory, Policy, and Implementation". Jakarta: PT.Bumi Aksara.

Mukti Fajar Nur Dewata and Yulianto Achmad. (2010). Dualism of Legal Research: Normative and Empirical. Yogyakarta: Pustaka Belajar.

Peter Mahmud Marzuki. (2008). Introduction to Legal Studies. Jakarta: Kencana.

Ronny Hanitijo Soemitro. (1990). Legal and Jurimetric Research Methodology. Jakarta: Ghalia Indonesia. 
Sulistyowati Irianto dan Shidarta. (2013). Legal Research Methods: Constellation and Reflection. Jakarta: Yayasan Pustaka Obor.

Winangun, Y. W.2004. Land of Life Value. Yogyakarta: Kanisius.

Alfred Nobel, Nabila Putri Larasati. (2017). "Land Financing Innovations for Toll Road Projects Included in National Strategic Projects Using a Bailout Fund Mechanism”, Jurnal HPJI Vol. 3, No. 2.

\section{Copyrights}

Copyright for this article is retained by the author(s), with first publication rights granted to the journal.

This is an open-access article distributed under the terms and conditions of the Creative Commons Attribution license (http://creativecommons.org/licenses/by/4.0/). 